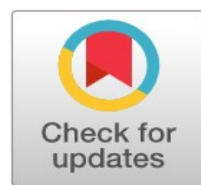

\title{
Financial crisis and determinants of capital structure of investment banking sector in Pakistan
}

\author{
Ajab Khan Burki * \\ Department of Management Science, Bahria University Islamabad, Pakistan
}

\author{
Index Terms \\ Capital structure \\ Investment banking sector \\ Financial crisis
}

Received: 15 April 2017

Accepted: 22 May 2017

Published: 30 June 2017

\begin{abstract}
The aim of this paper is to add in the incumbent literature of capital structure by estimating the capital structure's determinants of investment banking sector of Pakistan for the period of 2004-11 and the effect of the financial crisis (2007-08) on these determinants in deciding debt to equity choice on the firm level. This article utilizes the balanced panel econometric techniques for catering the said objectives. The previous works of notable scholars are thoroughly reviewed for capital structure. Similarly, the balanced panel econometric techniques are used for examining the implication of financial crisis on deciding for firm's financing. The effect is estimated by dividing the sample period into two parts: pre (2004-06) and post (2009-11) financial crisis. The outcomes suggest that determinants of capital structure are the same as utilized in the advanced economies. Besides, this paper entails a strong evidence of financial crisis' effect on capital structure's determinants in investment banking sector of Pakistan. This paper produces a fresh outlook into determining the capital structure's determinants from the perspective of investment banking sector of Pakistan. Secondly, this paper produces a valuable addition to the incumbent literature by determining the effect of the financial crisis on capital structure decision making based on the given determinants.
\end{abstract}

(c) 2017 The Author(s). Published by TAF Publishing.

\section{INTRODUCTION}

The effective operations of corporations can't run without sound financial resources. The firms devote a reasonable amount of time for catering an optimal capital structure decision for achieving significant growth and value. The inception of Modigliani \& Miller (MM) work in 1958 has opened a significant dimension in understanding the financing decisions of firms. The effect of financing decisions is mainly deliberated and discussed for developed economies while the same implications are not reasonably applied to developing countries' firms due to lack of updated data and comparatively varying infrastructural and cultural aspects. Thus the validity of determining the true effect of financing decision through defining the capital structure could be significantly determining the very appro- priate determinants. The aim of this research study is to estimate the determinants of capital structure of investment banking sector in Pakistan. This study is divided into two sub-parts: pre-financial crisis (2004-06) and post-financial crisis (2009-11). The requisite implications on profitability, liquidity, and tangibility would be estimated considering size as mediating variable. A little attention has been focused on researching the crucial area of capital structure's determinants particularly in less developed countries with specific concern to highlights with the perspective of Investment banking sector exclusively in the financial crisis of 2007-08. Though there is no doubt that financial recession in terms of capital structure determination has been deliberated by various researchers (For instance Erkens, Hung \& Matos 2012; Campello, Giambona, Graham \& Har-

\footnotetext{
* Corresponding author: Ajab Khan Burki

†Email: ajabburki07@gmail.com
} 
vey, 2011, Campello, Graham \& Harvey, 2010; Acharya \& Schnabl, 2010), yet a very little has been uncovered for estimating the implication of financial crisis on capital structure determinants of investment banking sector in developing economies like Pakistan. There were few studies (Like, Shah \& Khan, 2007; Ahmed Sheikh \& Wang, 2011; Ghani \& Bukhari, 2010; Kausar, Nazir \& Butt, 2014; Rafiq, Iqbal \& Atiq, 2008; Ahmed, Ahmed \& Ahmed, 2010) in the context of capital structure of financial firms working in Pakistan but they did not incorporate exclusively the implication of financial crisis on capital structure determinants of investment banking sector of Pakistan. This research article tries to fill in this gap and add the incumbent scope of knowledge. Therefore, this paper is mainly estimating the capital structure's determinants and the implication of financial crisis (2007-08) of the investment banking sector of Pakistan. Investment banking sector is of high significance in Pakistan because of four fundamental functions i.e. 1. Capital raising; 2. Merger and Acquisition; 3. Portfolio Management; and 4. Research. Pakistan is a progressive country and its economic activity has ever been expanded and developed due to financial and economic activities. The motivation of writing from this perspective is that Pakistan's economy is of crucial concern specifically from the point of view of fluctuating economic Imbalances over the period of times. Little attention has been given on to estimate the determinants of capital structure of Investment banks of Pakistan and in particular when the financial recession has erupted. The 9 Investment banks of Pakistan has been selected in this regard for determining the realistic effect of the financial crisis and determining the various determinants of capital structure. The arrangement of the requisite article is as follow: part-2 is theoretical background and hypotheses construction; part-3 deliberates the methodology of the incumbent study. part- 4 entails the outcomes of the tested hypotheses. Section- 5 concludes the whole research article.

\section{THEORY AND HYPOTHESES DEVELOPMENT}

Since Modigliani \& Miller propositions in 1958, the urge for coping up with to achieve the optimal capital structure and maximization of firm's value has started. The initial proposition was based on the premise that the values of levered and unleveraged firms are equal in the absence of taxes. The preceding stance was further amended in 1963 considering the benefit of tax benefits on debt financing. This necessitates that the worth in terms of the value of firm financed through leverage is greater than unleveraged firm because of tax advantage due to leverage. Modigliani
\& Miller (1977) further amended the preceding premise by considering personal taxation. There are two aspects of personal taxation: 1 . Taxation on income from shares; 2. Taxation on income from levered securities. They had identified certain particular outcomes where advantage from debt financing was around zero, giving the same outcomes as that of Modigliani \& Miller (1958). Therefore, it has been concluded that optimal capital structure is on a macro level rather on a micro level. Trade-off theory and pecking order theory has eventually emerged against the MM proposition presented in 1958. According to trade off theory, the determination of optimal capital structure is based on the tradeoff between rewards and costs the portion of equity and debt financing after having to consider the imperfection in the market due to agency costs, taxation, and bankruptcy. The reward from tax advantage should be adjusted to the cost of riskiness exposure. Therefore, it is essential to determine the level of debt to equity which may provide with optimal return i.e. having minimal costs and maximum rewards (Scott, 1977). The tradeoff theory is reasonably used for the firm's financing decision based on expectations in future (Luigi \& Sorin, 2009). The future prospects of the company in terms of information have been deliberated as asymmetric between managers and shareholders according to Pecking Order theory (Myers, 1984). Thus the motive of the capital structure of any firm for its investment is resided on mainly on preferably through the internally raised capital, followed by leverage and lastly through equity. This phenomenon of financing decision is derived by the cost of financing of the requisite source. The other related capital structure theories are agency cost theory, signaling theory, market timing theory and free cash flow theory. According to Jensen \& Mackling (1976), the conflict of interest is present among all stakeholders of the firms. Thus this agency cost theory is popularized due to considering for interests between managers and shareholders while deciding upon capital structure for the firm. The next capital structure's theory is signaling (Ross, 1977; Hoai \& Thanwadee, 2015). This theory also relies on information asymmetry. The firm that is taking a large volume of debt signifies by the incumbent investors that the organization is materializing high-quality operations in utilizing debts and that would reflect upon generation of healthy future cash flow as well. Therefore, it is inferred that the weak firms may not assume on taking more debts as it may further deteriorate the existing value of the firm and would cater higher chances of default and bankruptcy costs (Schoubben \& Van Hulle, 2004). The the- 
ory of market timing (Baker \& Wurgler , 2002) regarding capital structure especially when the deficit of firm deficit is to be financed. This theory is relatively new and very less debate in terms of testing is available. Though according to some tests for its validity has been conducted by Elliott, Koëter-Kant \& Warr (2007) that contended that the chances of issuing more shares to the already overvalued equity of firms to tackle the incumbent deficit are high as compared to undervalued. In order to control free cash that is otherwise not providing profit to the firm, debt is utilized by managers. According to Jensen (1986) has noticed though free cash flow theory, that management is more interested in to extend the optimal size of their projects and activities regardless of catering negative net present value. The main tool for controlling free cash flow to the requisite investors in the hands of management is to assume on more leverage. The capital structure theories have been tested for their validity based on various factors associated with the firm. Pecking order theory (Myers, 1984) concluded a negative association between profitability and leverage. The firm catering higher profitability is utilizing less debt financing for its investment. Due to the presence of information asymmetry between managers of firms and investors, there exists a hierarchy regarding defining a capital structure for the requisite firm (Myers \& Majluf, 1984). Therefore, the firm tries to utilize and relies upon internal capitals rather than debt financing to avert any diffusion of ownership and mandate. This phenomenon necessitates that the firm is only tilted to debt financing when internal capital through its own earnings are not sufficient. The managers categorically after internal earnings have to preferably rely on debt than equity when it is needed. This notion has been tested and estimated by many researchers. The notable researcher has determined negative association between profitability and debt financing of the firm (Zou \& Xiao, 2006; Chen \& Strange, 2005; Hall, Hutchinson \& Michaelas, 2004; Cassar \& Holmes, 2003; Fama \& French, 2002; Myers, 2001; Shyam-Sunder \& Myers, 1999; Wiwattanakantang, 1999; Barton, Hill \& Sundaram, 1989; Titman \& Wessels, 1988; Titman, 1984). Similarly, the firm signifies a high cadre of earnings/profits would opt for less debt financing that indicates a good signal in the market as compared to the firm having lower quality of profitability according to signalling theory (Schoubben \& Van Hulle, 2004).

H1: The anticipated association between profitability and leverage should be negative.

Asset tangibility is one of the key determinants of capital structure of corporations, particularly in the less developed countries where institutional infrastructure is meager to safeguard the rights of the creditors. Asset tangibility can be utilized as a proxy of collateral for taking debt. Therefore, it necessitates a positive association between asset tangibility and debt financing of the firm. Tradeoff and Pecking order theory, both endorse this relationship. One of the researchers has observed that having more tangible assets triggered more leverage for the firms (Bradley, Jarrell \& Kim, 1984; Layyinaturrobaniyah, Masyita \& Sekartadjie, 2016). The essence of this phenomenon is based on the lenders' confidence of having significant assets as collateral for liquidation if the firm would not comply as per obligations. The lending facility is relatively more convenient for the firms having more tangible assets to be kept as a guarantee as compared to the firms having fewer assets for a pledge against acquiring debt (Wiwattanakantang, 1999). Besides, according to Scott (1977), such firms are compelled to take debts more on the behest of issuing shares instead of debts. The positive association of tangibility based on fixed assets with that of debt financing is estimated through many studies (Deesomsak, Paudyal \& Pescetto, 2004; Huang, 2006; Viviani, 2008; Ahmed Sheikh \& Wang, 2011; Fosu, 2013).

H2: The anticipated association between tangibility and leverage should be positive.

Firms having more liquidity are normally tended to acquire more leverage from the perspective of tradeoff theory. The essence is simply the reasonably convenient capability of complying with the debt obligation on time (Ahmed Sheikh \& Wang, 2011). Various research studies have shown positive association of liquidity and leverage of the firms (like, De Jong, Kabir \& Nguyen, 2008).

H3: The anticipated association between liquidity and leverage should be positive.

The firm's size has to have significant impact on to decide about the capital structure of the firm. According to the notion of tradeoff theory, large firms are having more capital for investing in a portfolio which diversifies the riskiness across various assets. Hence the volatility in earnings is low. Large firms acquire more loans than smaller ones (Antoniou, Guney \& Paudyal, 2002). This means that firms' size is having a positive association with the leverage of the firm. Various empirical results have shown such relationships between these two variables (such as Wiwattanakantang, 1999; Wald, 1999; Deesomsak et al., 2004; Ahmed Sheikh \& Wang, 2011).

H4: The anticipated association between size of firm and leverage should be positive. 


\section{RESEARCH METHODOLOGY Sample and Data}

This research article examines capital structure of firm's level determinants as well as the implications of the financial crisis (2007-08) on the incumbent determinants of investment banking sector of Pakistan. The requisite data of the investment banking of capital structure determinants are collected from annual reports of the given corporations for the period of 2004-11. The data of nine investment banks are collected due to the availability of data. This particular sector has been taking based on motivation that no research has been exclusively done for investment banking sector of Pakistan and particularly its capital structure determinants in the financial crisis of 2007-08.

As discussed in the introduction, this research article has two prominent objectives to achieve:

1. To cater firm-level capital structure determinants of investment banking sector of Pakistan for the sample period of eight years (2004-11).

2. To estimate the implications of the financial crisis (2007-08) on these capital structure determinants of firmlevel.

The first part of the study is catered through taking the whole data of the explanatory variables (firm-level capital structure's determinants) for the period of 2004-11. The second part of this study is to divide the whole tenure's data into two sub-parts. The first sub-part utilizes data for the period of 2004-06 (pre-financial crisis era) and the second sub-part utilizes data from 2009-11 (post financial crisis era). Therefore the data of 2007-08 has been excluded as this was the timeline for financial crisis throughout the world.

TABLE 1. Variables and measurement

\begin{tabular}{ll}
\hline \hline Variable \& Abbreviation & Measurement \\
\hline Profitability (PROF) & EBIT/Total Firm's Assets \\
Liquidity (LIQ) & Total Current Assets/ Total Current Liabilities \\
Tangibility (TANG) & Fixed Assets/ Total Firm's Assets \\
Size of Firm (SF) & Log of Total Firm's Assets \\
Leverage (LEV) & Total Debt to Total Equity \\
\hline \hline
\end{tabular}

The given model determines the dependent variable and explanatory variables (Capital structure determinants of firm level) as follow:

Lev $=\beta_{0}+\beta_{1}$ Prof $+\beta_{2}$ Liq $+\beta_{3}$ Tang $+\beta_{4} S F+\epsilon$ ISSN: $2414-309 \mathrm{X}$

DOI: $10.20474 /$ jabs-3.3.5
TABLE 2 . Dependent variable: Leverage

\begin{tabular}{ll}
\hline \hline Explanatory Variables & Association with Dependent variable \\
\hline Profitability (PROF) & Negative \\
Liquidity (LIQ) & Positive \\
Tangibility (TANG) & Positive \\
Size of Firm (SF) & Positive \\
\hline \hline
\end{tabular}

\section{RESULTS}

\section{Summary of Descriptive Statistics}

The given Table 03 provides the descriptive statistics figures for both the dependent variable and explanatory variables of this study. The data is restricted to 9 investment banks of Pakistan for consecutive 8 years (i.e. 2004-11).

TABLE 3 . Descriptive statistics

\begin{tabular}{llllll}
\hline \hline & LEV & PROF & LIQ & TANG & SZ \\
\hline Mean. & 0.294306 & 0.434861 & 2.163194 & 0.085278 & 9.203764 \\
Median. & 0.275000 & 0.435000 & 2.125000 & 0.055500 & 9.250000 \\
Maximum. & 0.980000 & 0.950000 & 3.820000 & 0.910000 & 9.960000 \\
Minimum. & 0.000000 & -0.370000 & 0.200000 & 0.010000 & 8.020000 \\
Std. Dev. & 0.206806 & 0.228424 & 1.098166 & 0.145360 & 0.407334 \\
Skewness. & 0.350456 & -0.195274 & -0.110856 & 4.982829 & -0.654548 \\
Kurtosis. & 2.879159 & 4.255535 & 1.532797 & 28.24447 & 3.857303 \\
\hline \hline
\end{tabular}

There are few results to be noted: the total leverage constitutes around $29 \%$ worth of the total capital structure of the selected investment banking sector of Pakistan (mean value: 0.294306 ) which indicates that investment banking sector in Pakistan is sufficiently relying on internally generated capitals rather than debts for financing.

\section{Firm-Level Capital Structure Determinants' Implication on Leverage}

The given results are based on our sample for the whole period (i.e. 2004-11) of investment banking sector of Pakistan. The firm-level capital structure's determinants are taken to depict the due implication on leverage. This study caters three methods of estimation: a. Ordinary Least Square OLS method; $b$. the random effect and c. the fixed effect models.

The foremost method (OLS) is determined on the basis of no grouping or individual implications among the given sample of the requisite firms. To counter the problem of cross-sectional effect because of various firms considering over time, we deploy fixed effect model (Ahmed Sheikh \& Wang, 2011). The outcomes of these three methods are provided in Table 03. The appropriateness and suitability of random or fixed effect models, this study utilizes the Hausman specification test. There the given results are interpreted based on fixed effect model. 


\section{ANALYSIS AND DISCUSSION}

\section{Analysis of Outcomes of Firm-Level Capital Structure's Determinants}

The firm-level capital structure's determinants are taken to determine the impact on leverage. A set of definite hypotheses is developed to estimate the effect of all these firm-level

determinants on the leverage of investment banking sector of Pakistan for the whole sample period of 2004-11. The given table 03 produces with regression analyses results.

The anticipated first hypothesis is that profitability represented by PROF is negatively associated with leverage (LEV). The given hypothesis is maintained and supported by this study i.e. profitability is significantly negatively related to leverage of investment banking sector in Pakistan $(\beta=-0.385144, p=0.0000)$. This outcome is in line and consistent with the pecking order theory's expectation and prediction that professes the utilization of internally generated funds for investments rather than debt financing. The result of profitability also complies with that of signalling theory that dictates that profitable corporations are relatively having less reliance on debt financing (Schoubben \& Van Hulle, 2004).

This phenomenon can be linked to the high cost of debt. Therefore, it has been established that investment banks in Pakistan are sufficiently relying on using the internally generated funds. This research article is complying the empirical results of other studies in the same scope (like, Ahmed Sheikh \& Wang, 2011; Zou \& Xiao, 2006; Hall et al., 2004; Fama \& French, 2002; Wiwattanakantang, 1999). The anticipated association of liquidity and leverage is supported through the results of this study ( $\beta=0.110041, p=0.0000$ ). Therefore our second hypothesis is supported as per our said expectations.

The outcome of this research is showing positive association and relationship between liquidity and leverage of investment banks in Pakistan. There could be a possibility that management may utilize liquid assets for shareholders' interests contrary to debt-holders (Deesomsak et al., 2004). Hence, such phenomenon leads to create a negative association between liquidity and debt financing. Other studies related to developing economies have determined the similar association between the given two variables (like, Ahmed Sheikh \& Wang, 2011; Viviani, 2008). Our next hypothesis based on the premises that assets' tangibility is positively associated with leverage is supported through our results ( $\beta=0.033586, p=0.6933$ ) but it is insignificant. This validity shows tangible and fixed assets could not be utilized as guarantee and collateral for acquiring loans in Pakistan.

As it is established phenomenon that high tangibility of assets repose more trust for the creditors yet the possibility in terms of investment banks in Pakistan is otherwise could be due to reason that the dependency on debt financing is effectively very low. This means that raising capital through debt could be arranged otherwise based on financial performance and credit rating. The fourth hypothesis of this paper is supported and significant at $10 \%$ level of confidence ( $\beta=0.139468, p=0.0825)$. The size of the firm is positively associated with leverage. This may be probably due to the reason that the corporations under this study are roughly of the same sizes.

TABLE 4 . Regression outcomes for the whole period (2004-11)

\begin{tabular}{llcc}
\hline \hline $\begin{array}{l}\text { Dep. Variable: Leverage } \\
\text { Explanatory Variables }\end{array}$ & oLS & Random Effect & Fixed Effect \\
\hline PROF & $-0.441763(0.0000)^{*}$ & $-0.399896(0.0000)^{*}$ & $-0.385144(0.0000)^{*}$ \\
LIQ & $0.098426(0.0000)^{*}$ & $0.106127(0.0000)^{*}$ & $0.110041(0.0000)^{*}$ \\
TANG & $0.037406(0.6562)$ & $0.015894(0.8431)$ & $0.033586(0.6933)$ \\
SZ & $-0.001434(0.9603)$ & $0.016732(0.6657)$ & $0.139468(0.0825)^{* * *}$ \\
No of Observations: & 72 & 72 & 72 \\
Prof $>F$ & 0.000000 & 0.000000 & 0.000000 \\
$R^{2}$ & 0.808195 & 0.782343 & 0.886241 \\
\hline \hline \multicolumn{4}{l}{-values are in parentheses, whereas ${ }^{* * *},{ }^{* *},{ }^{*}$ symbolizes $10 \%, 5 \%, 1 \%$} \\
Significance level.
\end{tabular}

\section{Analysis of Outcomes of Firm-Level Capital Structure's Determinants Considering the Implication of Financial Crisis (Pre and Post Analysis)}

Since the financial crisis (can also be termed as Global Financial Crisis of 2007-08) was on a macro level that was having its due implications everywhere throughout the global economies. The investment banks are highly affected throughout the world (Ross, 1977; Lindsay, Ashill \& Victorio, 2007). Similarly, the effect of such huge macro imbalances can't be excluded in terms of its effect on investment banking sector of Pakistan as it spills over contagiously to other countries (Deesomsak et al., 2004; Cheng \& Shiu, 2007). It is highly essential to determine the effect of the financial crisis of 2007-08 on the capital structure decision making in investment banking sector of Pakistan for comprehending the true picture of financing mix during that period. This part is sub-divided into two parts: subpart-1 determines the regression results of pre-financial crisis for the period of 2004-06 (i.e. 3 years) and subpart2 repre sents the regression results of post-financial crisis for the period of 2009-11 (i.e. 3 years). The financial crisis has affected the capital structure's determinants of investment banks working in Pakistan like elsewhere in the advanced economies. The association between profitability and leverage is negative in both pre and post financial crisis. However, the relationship in pre-financial crisis is signifi-

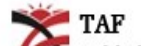


cant $(\beta=-0.531242, p=0.0000)$ while it is insignificant $(\beta=$ $-0.176985, p=0.1162$ ) at $10 \%$ level of confidence in postfinancial crisis. Thus the results depict that pre-financial crisis' profitability determinant is significant due to the fact that the acquisition of debts from lender was effective based on sufficient profitability of the given firms. While in the

later part of the post-financial crisis, the lenders could not be reasonably be influencing from the incumbent firms for granting debts exclusively on profitability benchmark. Tangible assets are crucial for acquiring loans from the incumbent lenders. The firms having more tangible assets are relatively in a better position to produce collateral to the lender as a guarantee in case of insolvency. This collateralized security emboldens the confidence of requisite lenders for overcoming imminent credit risk if any. The financial crisis has significantly affected this crucial determinant of the capital structure in investment banking sector of Pakistan. Before financial crisis (2004-06), tangibility (TANG) was significant at $1 \%(\beta=0.170411, p=0.0033)$ level while this determinants remained significant at $5 \%$ level $(\beta=1.691434, p=0.0136)$ in post-financial crisis period (2009-11) too. Therefore, tangibility is always been one of the predominant determinants of capital structure decision making in investment banking of Pakistan. The significance of liquidity as one of the key determinants is not changed due to the crisis as it is evident from the prefinancial crisis $(\beta=-0.106034, p=0.0000)$ and post-financial crisis $(\beta=-0.103241, p=0.0000)$ results. Both of coefficients are negative and significant in pre and post financial crisis. Besides size of the firms are not significant both in pre (size coefficient: 0.003180 , P-Value: 0.9124 ) and post ( $\beta=0.051813, p=0.2351$ ) financial crisis as defining determinants of capital structure decision in investment banking sector of Pakistan primarily due to the reason that the firms selected for this study are almost of the similar size.

TABLE 5. Regression outcomes (Pre and post financial crisis)

\begin{tabular}{llc}
\hline \hline $\begin{array}{l}\text { Dep. Variable: Leverage } \\
\text { Explanatory Variables }\end{array}$ & Pre-Financial Crisis (2004-06) & Post Financial Crisis (2009-11) \\
\hline PROF & $-0.531242(0.0000)^{*}$ & $-0.176985(0.1162)$ \\
LIQ & $-0.106034(0.0000)^{*}$ & $-0.103241(0.0000)^{*}$ \\
TANG & $0.170411(0.0033)^{*}$ & $1.691434(0.0136)^{*}$ \\
SZ & $0.003180(0.9124)$ & $0.051813(0.2351)^{* *}$ \\
No of Observations: & 27 & 27 \\
Prof $>F$ & 0.000000 & 0.000000 \\
$R^{2}$ & 0.959004 & 0.877271 \\
\hline \hline & $p$-values are in parentheses, whereas $* * *, * *, *$ \\
significance level.
\end{tabular}

The overall analysis based on these findings clearly indicates that financial crisis (2007-08) posted a dreadful situation for the investment banking sector of Pakistan. This crisis necessitated the changing in capital structure decision making based on the given leading one's determinants.

\section{CONCLUSION}

Since the significant contribution of Modigliani \& Miller (1958) in the sphere of capital structure, various scholars have come up with predominantly crucial determinants of firm-level capital structure while deciding for financing. The main objectives of this paper are two-folds: 1 . to determine the capital structure's determinants of investment banking in Pakistan and 2. to determine the effect of the financial crisis (2007-08) on these factors of capital structure.

The intuition was based on whether factors of a capital structure determined in advanced economies are reflecting upon in our financial markets and exclusively in investment banking sector of Pakistan as this sector has not been taken so far for such consideration. This study caters of 9 leading investment banks of Pakistan for the period of 2004-11. Balanced panel econometric techniques are used for both objectives to be tested.

This study produces results of indicating that capital structure's determinants and its evidence for implication due to the financial crisis are not varying i.e. changes in leverage is advanced countries are also applicable in investment banking sector of Pakistan. This research has produced significant outcomes which comply with past studies in this domain i.e. this study cater to support trade-off and pecking order theories.

Secondly, this article examines the impact of financial recession/crisis (2007-08) on determinants/factors of the capital structure of investment banks in Pakistan which reflects financial restriction, especially during this era like profitability (PROF) and asset tangibility (TANG), are greatly affected due to the financial crisis. Therefore, this study is one of value addition to the incumbent literature by understanding the determinants/factors of the capital structure of firm level of investment banking sector of Pakistan and predominantly the implication of financial crisis on it.

\section{REFERENCES}

Ahmed, N., Ahmed, Z., \& Ahmed, I. 2010. Determinants of capital structure: A case of life insurance sector of Pakistan. Eu- ropean Journal of Economics Finance \& Administrative Sciences, 24: 7-12. 
Ahmed Sheikh, N., \& Wang, Z. 2011. Determinants of capital structure: An empirical study of firms in manufacturing indus- $\quad$ try of Pakistan. Managerial Finance, 37(2): 117-133. DOI: 10.1108/03074351111103668

Acharya, V.V., \& Schnabl, P. 2010. Do global banks spread global imbalances? Asset-backed commercial paper during the financial crisis of 2007-09. IMF Economic Review, 58(1): 37-73. DOI: 10.1057/imfer. 2010.4

Antoniou, A., Guney, Y., \& Paudyal, K. 2002. Determinants of corporate capital structure: Evidence from the European countries (Working paper). University of Durham, Durham, UK.

Baker, M., \& Wurgler, J. 2002. Market timing and capital structure. The Journal of Finance, 57(1): 1-32.

DOI: $10.1111 / 1540-6261.00414$

Barton, S.L., Hill, N.C., \& Sundaram, S. 1989. An empirical test of stakeholder theory predictions of capital structure. Finan-

Management, 18(1): 36-44. DOI: 10.2307/3665696

Bradley, M., Jarrell, G.A., \& Kim, E. 1984. On the existence of an optimal capital structure: Theory and evidence. The Journal of Finance, 39(3): 857-878. DOI: 10.1111/j.1540-6261.1984.tb03680.x

Campello, M., Giambona, E., Graham, J.R., \& Harvey, C.R. 2011. Liquidity management and corporate investment during a financial crisis. Review of Financial Studies, 24(6): 1944-1979. D0I: 10.1093/rfs/hhq131

Campello, M., Graham, J.R., \& Harvey, C.R. 2010. The real effects of financial constraints: Evidence from a financial crisis. Journal of Financial Economics, 97(3): 470-487. DOI: 10.1016/j.jfineco.2010.02.009

Cassar, G., \& Holmes, S. 2003. Capital structure and financing of SMEs: Australian evidence. Accounting \& Finance, 43(2): 123-147. DOI: 10.1111/1467-629X.t01-1-00085

Chen, J., \& Strange, R. 2005. The determinants of capital structure: Evidence from Chinese listed companies. Economic Change \& Restructuring, 38(1): 11-35. D0I: 10.1007/s10644-005-4521-7

Cheng, S.R., \& Shiu, C.Y. 2007. Investor protection and capital structure: International evidence. Journal of Multinational Financial Management, 17(1): 30-44. DOI: 10.1016/j.mulfin.2006.03.002

De Jong, A., Kabir, R., \& Nguyen, T.T. 2008. Capital structure around the world: The roles of firm-and country-specific deter- $\quad$ minants. Journal of Banking \& Finance, 32(9): 1954-1969. DOI: 10.1016/j.jbankfin.2007.12.034

Deesomsak, R., Paudyal, K., \& Pescetto, G. 2004. The determinants of capital structure: Evidence from the Asia Pacific region. Journal of Multinational Financial Management, 14(4): 387-405. D0I: 10.1016/j.mulfin.2004.03.001

Elliott, W. B., Koëter-Kant, J., \& Warr, R.S. 2007. A valuation-based test of market timing. Journal of Corporate Finance, 13(1): 112-128. DOI: 10.1016/j.jcorpfin.2006.12.001

Erkens, D.H., Hung, M., \& Matos, P. 2012. Corporate governance in the 2007-2008 financial crisis: Evidence from financial institutions worldwide. Journal of Corporate Finance, 18(2): 389-411. DOI: 10.1016/j.jcorpfin.2012.01.005

Fama, E.F., \& French, K.R. 2002. Testing trade-off and pecking order predictions about dividends and debt. Review of Finan- cial Studies, 15(1): 1-33. DOI: 10.1093/rfs/15.1.11

Fosu, S. 2013. Capital structure, product market competition and firm performance: Evidence from South Africa. The Quar- $\quad$ terly Review of Economics \& Finance, 53(2): 140-151. D0I: 10.1016/j.qref.2013.02.004

Ghani, K., \& Bukhari, S.H. 2010. Determinants of capital structure: A case of listed energy sector companies in Pakistan.

European Journal of Economics Finance \& Administrative Sciences, 2(24): 1-9. D0I: 10.2139/ssrn.1860706

Hall, G.C., Hutchinson, P.J., \& Michaelas, N. 2004. Determinants of the capital structures of European SMEs. Journal of

Busi- $\quad$ ness Finance \& Accounting, 31(5-6): 711-728. DOI: 10.1111/j.0306-686X.2004.00554.x

Huang, G. 2006. The determinants of capital structure: Evidence from China. China Economic Review, 17(1): 14-36.

DOI: $10.1016 /$ j.chieco.2005.02.007

Hoai, N.N., \& Thanwadee, H. 2015. Investigating factors influencing profits enhancement in real estate companies in Ho Chi Minh City, Viet Nam. International Journal of Business \& Administrative Studies, 1(3): 107-113.

DOI: 10.20469 /ijbas.10005-3

Jensen, M.C. 1986. Agency costs of free cash flow corporate finance and takeovers. The American Economic Review, 76(2): 323-329.

Jensen, M.C., \& Meckling, W.H. 1976. Theory of the firm: Managerial behavior agency costs and ownership structure. 
Jour- nal of Financial Economics, 3(4): 305-360. DOI: 10.1016/0304-405X(76)90026-X

Kausar, A., Nazir, M.S., \& Butt, H.A. 2014. Capital structure and firm value: Empirical evidence from Pakistan. Asian Journal of Research in Economics \& Finance, 1(1): 11-22.

Luigi, P. \& Sorin, V. 2009. A review of the capital structure theories. Annals of Faculty of Economics, 3(1): 315-320.

Layyinaturrobaniyah., Masyita, D., \& Sekartadjie, G. 2016. Fundamental and technical analyses for stock investment decision making. Journal of Administrative \& Business Studies, 2(1): 1-7. DOI: 10.20474/jabs-2.1.1

Modigliani, F., \& Miller, M.H. 1963. Corporate income taxes and the cost of capital: A correction. The American Economic Review, 53(3): 433-443.

Modigliani, F., \& Miller, M.H. 1958. The cost of capital, corporation finance and the theory of investment. The American Economic Review, 53(8): 261-297.

Myers, S.C. 1984. The capital structure puzzle. The Journal of Finance, 39(3): 574-592. DOI: 10.2307/2327916

Myers, S.C. 2001. Capital structure. Journal of Economic Perspectives, 15(2): 81-102. D0I: 10.1257/jep.15.2.81

Myers, S.C., \& Majluf, N.S. 1984. Corporate financing and investment decisions when firms have information that investors do not have. Journal of Financial Economics, 13(2): 187-221. DOI: 10.1016/0304-405X(84)90023-0

Rafiq, M., Iqbal, A., \& Atiq, M. 2008. The determinants of capital structure of the chemical industry in Pakistan . The Lahore Journal of Economics, 13(1): 139-158.

Ross, S.A. 1977. The determinants of financial structure: The incentive-signalling approach. The Bell Journal of Economics, 8(1): 23-40. DOI: $10.2307 / 3003485$

Lindsay, V., Ashill, N., \& Victorio, A. 2007. An institutional view of local entrepreneurial climate. Journal of Asia En- $\quad$ trepreneurship \& Sustainability, 3(1), 1-10.

Schoubben, F., \& Van Hulle, C. 2004. The determinants of leverage: Differences between quoted and unquoted firms.

Tijd- $\quad$ schrift Voor Economie En Management, 49(4): 589-622.

Scott, J.H. 1977. Bankruptcy secured debt and optimal capital structure. The Journal of Finance, 32(1): 1-19.

DOI: 10.1111/j.1540-6261.1977.tb03237.x

Shah, A., \& Khan, S. 2007. Determinants of capital structure: Evidence from Pakistani panel data . International Review of Business Research Papers , 3(4): 265-282.

Shyam-Sunder, L., \& Myers, S.C. 1999. Te sting static trade off against pecking order models of capital structure. Journal of

Financial Economics, 51(2): 219-244. DOI: 10.1016/S0304-405X(98)00051-8

Titman, S. 1984. The effect of capital structure on a firm's liquidation decision. Journal of Financial Economics, 13(1):

137-151. DOI: 10.1016/0304-405X(84)90035-7

Titman, S., \& Wessels, R. 1988. The determinants of capital structure choice. The Journal of Finance, 43(1): 1-19.

DOI: $10.1111 / j .1540-6261.1988 . t b 02585 . x$

Viviani, J.L. 2008. Capital structure determinants: An empirical study of French companies in the wine industry. Interna- tional Journal of Wine Business Research, 20(2): 171-194. D0I: 10.1108/17511060810883786

Wald, J.K. 1999. How firm characteristics affect capital structure: An international comparison. Journal of Financial Re- $\quad$ search, 22(2): 161-187. DOI: 10.1111/j.1475-6803.1999.tb00721.x

Wiwattanakantang, Y. 1999. An empirical study on the determinants of the capital structure of Thai firms. Pacific-Basin

Finance Journal, 7(3): 371-403. DOI: 10.1016/S0927-538X(99)00007-4

Zou, H., \& Xiao, J.Z. 2006. The financing behaviour of listed Chinese firms. The British Accounting Review, 38(3): 239-258.

DOI: $10.1016 /$ j.bar.2006.04.008

— This article does not have any appendix. - 